Tchon $\mathrm{Li}^{*}$

\title{
REGION GRODZIEŃSKI W MIĘDZYNARODOWYCH STOSUNKACH EKONOMICZNYCH
}

Handel zagraniczny tradycyjnie jest zaliczany do podstawowych czynników stałego wzrostu ekonomicznego i rozwoju gospodarki narodowej. Jest to jak najbardziej korzystne dla Białorusi zaliczanej do małych krajów z „otwartą” gospodarką ograniczoną przez konsumpcję wewnętrzną oraz deficyt własnych zasobów materialnych. W artykule są badane problemy rozwoju działalności przedsiębiorstw regionu grodzieńskiego $\mathrm{w}$ zakresie handlu zagranicznego $\mathrm{w}$ warunkach kryzysu światowego (lata 2008-2010). Wyniki ekonomiczne rozwoju stosunków w handlu zagranicznym wskazały, że przedkryzysowa ocena stopnia stałości była w pewnym stopniu zawyżona. Spadek wielkości obrotu w handlu zagranicznym, zwłaszcza w 2009 r., wymaga bardziej szczegółowej oceny osiągniętych wyników, wskazania przyczyn wpływających na ich stan oraz określenia priorytetów w podniesieniu efektywności rozwoju stosunków międzynarodowych regionu.

Oddziaływanie czynników wewnętrznych na gospodarkę regionu w krótkim okresie oczywiście nie mogło zasadniczo się zmienić; zaliczane do tej grupy czynniki zasobowe nadal posiadają niebogaty potencjał przyrodniczo-zasobowy i naukowo-techniczny; czynniki informacyjno-prawne - niewystarczająco efektywną bazę prawną i informacyjną; czynniki społeczno-ekonomiczne - słabą konkurencyjność podmiotów gospodarczych, niewystarczająco rozwinięty marketing przedsiębiorstw nastawionych na eksport. Wyjątkowo negatywnie wpływa na rozwój ekonomiczny stan struktury i specjalizacji gospodarki regionu, któremu właściwe są przede wszystkim duże wydatki zasobowe na produkcję oraz produkcja o niewysokim stopniu przeróbki, a więc odpowiedni wskaźnik wartości dodanej. Zaistniała struktura branży przemysłu regionu nie w pełni odpowiada jego zasobom terytorialnym, bezpieczeństwu ekologicznemu oraz w pewnym stopniu zasobom lokalnym.

Charakteryzując czynniki polityczno-administracyjne, warto zaznaczyć, iż korzystny wpływ na gospodarkę wywierany przez zaistniałą w latach zerowych stabilność polityczną został zminimalizowany przez niski ranking międzynarodowy dla

\footnotetext{
Kierownik Katedry Państwowego Uniwersytetu im. Janki Kupały w Grodnie na Białorusi.
} 
kredytów i inwestycji. Jednak najbardziej negatywnie na rozwój stosunków w handlu zagranicznym oddziałują czynniki zewnętrzne, do których należy zaliczyć światową koniunkturę towarów eksportowych, międzynarodowe programy wspierania, nasilenie środków protekcjonistycznych w pewnych państwach zagranicznych, stan gospodarki w międzynarodowych zgrupowaniach ekonomiczno-politycznych, przede wszystkim w WNP z dominującą rolą Rosji w gospodarce tej formacji.

W sumie wewnętrzne i zewnętrzne czynniki wywarły negatywny wpływ na stan stosunków w handlu zagranicznym w okresie kryzysu, zwłaszcza w 2009 r., i to spowodowało spadek produkcji, malejący popyt na produkcję produkcyjno-techniczną i towary powszechnego użytku ze strony podstawowego partnera Rosji w handlu zagranicznym, a z tego powodu obniżenie poziomu cen eksportowych w kilku gałęziach gospodarki regionalnej. Mimo że w 2010 r. warunki eksportu się polepszyły, już nie dało się osiągnąć poziomu $2008 \mathrm{r}$.

Tabela 1. Wskaźniki ogólnej oceny handlu zagranicznego towarami regionu grodzieńskiego

\begin{tabular}{|c|c|c|c|c|c|c|c|c|c|c|c|c|}
\hline \multirow[t]{2}{*}{ Lata } & \multicolumn{4}{|c|}{$\begin{array}{l}\text { Obrót w handlu zagranicznym } \\
\qquad(\mathrm{mnl} \text { USD) }\end{array}$} & \multicolumn{2}{|c|}{$\begin{array}{c}\text { Dynamika } \\
(\%) \\
2008 \text { roku }\end{array}$} & \multicolumn{2}{|c|}{$\begin{array}{l}\text { Wskaźnik } \\
\text { na głowę } \\
\text { mieszkańca } \\
\text { (tys. USD) }\end{array}$} & \multicolumn{2}{|c|}{$\begin{array}{c}\text { Udział } \\
\text { w handlu } \\
\text { zagranicznym } \\
\text { kraju }\end{array}$} & \multirow{2}{*}{ 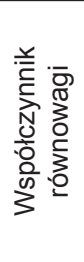 } & \multirow{2}{*}{ 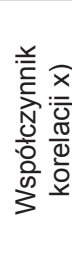 } \\
\hline & 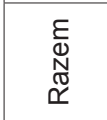 & $\begin{array}{l}\frac{t}{0} \\
\frac{0}{n} \\
\frac{D}{\Psi}\end{array}$ & $\begin{array}{l}\text { t̄ } \\
\stackrel{\circ}{E}\end{array}$ & $\frac{\circ}{\frac{0}{\pi}}$ & $\begin{array}{l}E \\
\mathbb{N} \\
\mathbb{N} \\
\widetilde{Y}\end{array}$ & 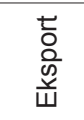 & $\begin{array}{l}\varepsilon \\
\mathbb{N} \\
\mathbb{N} \\
\check{N}\end{array}$ & $\begin{array}{l}\frac{t}{0} \\
\frac{0}{0} \\
\frac{2}{4}\end{array}$ & 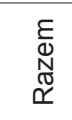 & $\begin{array}{l}\frac{t}{0} \\
\frac{0}{0} \\
\stackrel{\sim}{\Psi}\end{array}$ & & \\
\hline 2008 & 3073,1 & 1564,0 & 1509,1 & 54,9 & - & - & 2,8 & 1,5 & 4,3 & 4,8 & 1,04 & 0,96 \\
\hline 2009 & 2403,9 & 1253,1 & 1150,8 & 102,3 & 78,2 & 80,1 & 2,2 & 1,2 & 4,8 & 5,9 & 1,09 & 0,78 \\
\hline 2010 & 2972,2 & 1628,8 & 1343,4 & 285,4 & 96,7 & 104,1 & 2,8 & 1,5 & 5,0 & 6,4 & 1,21 & 0,94 \\
\hline
\end{tabular}

Źródło: Opracowanie własne.

Jak wynika z tabeli 1, następstwa kryzysu gospodarki światowej przyczyniły się do stanu handlu zagranicznego regionu. Wskaźnik obrotu w handlu zagranicznym w 2009 r. w porównaniu z najlepszym dla kraju z okresu kryzysowego rokiem 2008 spadł do 0,78 i chociaż sytuacja w 2010 r. uległa polepszeniu, jednak nie osiągnęła poziomu przedkryzysowego, wskaźnik wyniósł 0,94. Bardziej zauważalna jest dynamika eksportu, po 20\% spadku w 2009 r. jego wielkość w 2010 r. przekroczyła poziom 2008 r. o 4,1\%. Zwróćmy uwagę na zwiększenie udziału regionu w ogólnokrajowym obrocie handlu zagranicznego do 5\%, w eksporcie do 6,4\%, lecz spowodowane to jest przez spadek obrotu $\mathrm{w}$ handlu zagranicznym $\mathrm{w}$ mniejszym stopniu niż w całym kraju (2010 r. w stosunku do 2008 r. obwód grodzieński - 97\%, Białoruś $-83 \%$ ). Udział eksportu w obrocie handlu zagranicznego w regionie wzrósł 
Region grodzieński...

z 50,9\% (2008 r.) do 54,8\% (2010 r.) i to zmieniło współczynnik równowagi handlu zagranicznego - 1,21.

Jeśli przyjrzymy się osiągniętym wynikom, wychodząc z założenia minimalizacji oraz dalszej likwidacji ujemnego salda w handlu zagranicznym kraju, ocenić je należy jako niewystarczające, czego dowodem jest obniżenie współczynnika korelacji poniżej 1, oznacza to bowiem opóźnienie tempa wzrostu eksportu w stosunku do dynamiki produkcji przemysłowej. W poprzednim pięcioleciu średnioroczne tempo wzrostu eksportu wynosiło 149,6\%, średni współczynnik równowagi handlu zagranicznego - 1,35, udział eksportu regionalnego w eksporcie kraju już w 2003 r. wynosił 6,7\%. Zatem w 1. 2008-2010 pod względem kilku wskaźników handlu zagranicznego region nieznacznie cofnął się, w porównaniu z wynikami sprzed 5 lat. Mimo pewnego wzrostu wskaźników eksportu produkcji na głowę mieszkańca, opóźnienie zarówno regionu, jak i kraju w stosunku większości krajów europejskich jest dość duże, o czym świadczą dane tabeli 2.

Tabela 2. Eksport produkcji na głowę mieszkańca w niektórych krajach europejskich (2008 r.)

\begin{tabular}{|c|c|c|c|}
\hline Nazwa kraju & $\begin{array}{c}\text { Eksport } \\
(\mathrm{mln} \text { USD })\end{array}$ & $\begin{array}{c}\text { Liczba mieszkańców } \\
\text { (mln osób) }\end{array}$ & $\begin{array}{c}\text { Eksport na głowe } \\
\text { mieszkańca (tys. USD) }\end{array}$ \\
\hline Czechy & 146,8 & 10,4 & 14,1 \\
\hline Słowacja & 71,0 & 5,4 & 13,1 \\
\hline Węgry & 108,0 & 10,6 & 10,2 \\
\hline Estonia & 12,5 & 1,4 & 8,9 \\
\hline Litwa & 23,7 & 3,4 & 7,0 \\
\hline Łotwa & 10,1 & 2,3 & 4,4 \\
\hline Polska & 169,1 & 38,6 & 4,4 \\
\hline Bułgaria & 22,6 & 7,5 & 3,0 \\
\hline Białoruś & 32,6 & 9,8 & $3,3^{\mathrm{x})}$ \\
\hline obwód grodzieński & 1,6 & 1,1 & $1,5^{\times)}$ \\
\hline
\end{tabular}

Źródto: Opracowanie własne.

W 2010 r. eksport na głowę mieszkańca wyniósł w RB - 2,5 tys. USD, w obwodzie grodzieńskim - 1,45 tys. USD.

Podany w tabeli 2 wykaz krajów zawiera niektóre byłe republiki radzieckie oraz państwa, które wcześniej były członkami zjednoczenia polityczno-gospodarczego RWPG o identycznej strukturze gospodarki narodowej oraz jeszcze do niedawna podobnej organizacji i zarządzaniu gospodarką. Jeśli chodzi o europejskie 
Tchon Li

„grandy” gospodarcze, jak np. Niemcy, Wielką Brytanię, Francję, Włochy, Belgię, Austrię, to osiągnięty tam poziom eksportu na głowę mieszkańca o wiele przekracza wyniki w naszym kraju, chociaż w strukturze handlu tych krajów brakuje takich pozycji ,walutowych” jak produkty naftowe i gaz.

\section{Struktura terytorialno-geograficzna handlu zagranicznego}

Z badań nad transakcjami eksportowo-importowymi obwodu grodzieńskiego wynika, że podstawowymi partnerami handlowymi były kraje z dwu ugrupowań polityczno-gospodarczych - WNP i UE. W 2010 r. przypadało na nie 81\% obrotu w handlu zagranicznym oraz $80 \%$ eksportu (tabela 3 ).

Tabela 3. Udział krajów WNP oraz krajów spoza WNP w handlu zagranicznym towarami regionu grodzieńskiego

\begin{tabular}{|c|c|c|c|c|c|c|c|c|c|}
\hline \multirow{4}{*}{ Rok } & \multirow{4}{*}{$\begin{array}{l}\text { Cały } \\
\text { świat }\end{array}$} & \multicolumn{2}{|c|}{ Kraje WNP } & \multicolumn{6}{|c|}{ Kraje spoza WNP } \\
\hline & & \multirow{3}{*}{$\begin{array}{l}\text { Razem } \\
\text { mln } \\
\text { USD }\end{array}$} & \multirow{3}{*}{$\begin{array}{c}\text { Udział w handlu } \\
\text { zagranicznym } \\
(\%)\end{array}$} & \multirow{3}{*}{$\begin{array}{l}\text { Razem } \\
\text { mln } \\
\text { USD }\end{array}$} & \multicolumn{2}{|c|}{ W tym } & \multirow{2}{*}{\multicolumn{3}{|c|}{$\begin{array}{c}\text { Udział w handlu } \\
\text { zagranicznym, \% }\end{array}$}} \\
\hline & & & & & \multirow{2}{*}{ UE-27 } & \multirow{2}{*}{$\begin{array}{l}\text { Inne } \\
\text { kraje }\end{array}$} & & & \\
\hline & & & & & & & Razem & UE-27 & $\begin{array}{l}\text { Inne } \\
\text { kraje }\end{array}$ \\
\hline \multicolumn{10}{|c|}{ Obrót handlu zagranicznego } \\
\hline 2008 & 3073,1 & 1378,7 & 44,9 & 1694,4 & 1212,4 & 482,0 & 55,1 & 39,5 & 15,6 \\
\hline 2009 & 2403,9 & 977,0 & 406 & 1426,9 & 1010,2 & 416,7 & 59,4 & 42,0 & 17,4 \\
\hline 2010 & 2972,2 & 1400,8 & 47,1 & 1570,3 & 1014,8 & 556,5 & 52,9 & 34,0 & 18,9 \\
\hline \multicolumn{10}{|c|}{ Eksport } \\
\hline 2008 & 1564,0 & 931,0 & 59,5 & 633,0 & 350,7 & 282,3 & 40,5 & 22,4 & 18,1 \\
\hline 2009 & 1253,1 & 726,2 & 58,0 & 526,9 & 280,8 & 246,1 & 42,0 & 22,4 & 19,6 \\
\hline 2010 & 1628,8 & 1026,2 & 63,0 & 602,5 & 276,4 & 326,1 & 37,0 & 16,9 & 20,1 \\
\hline \multicolumn{10}{|c|}{ Import } \\
\hline 2008 & 1509,1 & 447,7 & 29,7 & 1061,4 & 861,7 & 199,7 & 70,3 & 57,1 & 13,2 \\
\hline 2009 & 1150,8 & 250,8 & 21,8 & 900,0 & 729,4 & 170,6 & 78,2 & 63,4 & 14,8 \\
\hline 2010 & 1343,4 & 374,6 & 27,9 & 967,8 & 738,4 & 230,4 & 70,6 & 54,9 & 15,7 \\
\hline \multicolumn{10}{|c|}{ Saldo } \\
\hline 2008 & 54,9 & 483,3 & & $-428,4$ & $-511,0$ & 82,6 & & & \\
\hline 2009 & 102,3 & 475,4 & & $-373,1$ & $-448,6$ & 75,5 & & & \\
\hline 2010 & 286,3 & 631,6 & & $-345,3$ & $-461,0$ & 95,7 & & & \\
\hline
\end{tabular}

Źródło: Opracowanie własne.

W analizowanym okresie handel zagraniczny z krajami WNP wciąż miał charakter priorytetowy (47\% obrotu handlu zagranicznego i 63\% eksportu w 2010 r.), w tym samym roku osiągnięto przedkryzysowy poziom handlu zagranicznego, a eksport zwiększono o 10,2\%. Jeśli chodzi o import z krajów WNP, to w okresie przedkryzysowym spadł on o $12 \%$, a jego udział w handlu zagranicznym do 
29,4\%. Dominującym partnerem w handlu z krajami WNP nadal jest Rosja, z którą procesy integracji są najdalej posunięte. W 2010 r. udział Rosji z handlu zagranicznym regionu z krajami WPN wyniósł $81,9 \%$, w eksporcie - 84,7\%. Kwota handlu zagranicznego drugiego co do znaczenia partnera handlowego - Ukrainy - wyniosła 11,3\%, kwota eksportu - 8,1\%. Najszybciej rozwijał się handel z Kazachstanem, w 2010 r. w porównaniu do 2008 r. wymiana handlowa zwiększyła się o16\%, eksport - o 58\%, jednak osiągnięte wyniki nie odpowiadają możliwościom gospodarczym tego szybko rozwijającego się kraju. Kwota eksportu Kazachstanu wynosi $2,7 \%$, natomiast handlu zagranicznego jest jeszcze niższa - 2,1\%. Bardzo słabo rozwijają się stosunki handlu zagranicznego z pozostałymi członkami WNP. Przypada na nie tylko 4,7\% obrotu regionalnego z krajami WNP oraz 4,5\% eksportu. Rosyjski rynek dominuje także w handlu z krajami Eurazjatyckiej Wspólnoty Gospodarczej (Eurasec) oraz Unii Celnej (UC), których członkiem jest również RB. W obrocie handlu zagranicznego regionu z krajami WNP na kraje UC przypada 97,5\%, na kraje Eurasec - 94\%.

Handel zagraniczny z krajami UE jest bardziej zdywersyfikowany. UE jest jednym z największych obszarów planety, co do swojego potencjału produkcyjnego, naukowo-technicznego, ekonomicznego i finansowego; produkuje jedną trzecią światowego PKB; lokuje za granicą połowę swoich inwestycji. Rozszerzanie zewnętrznych stosunków gospodarczych z krajami członkowskimi UE korzystnie wpływa na konkurencyjność podmiotów gospodarczych, wzrost technicznego poziomu produkcji, wdrażanie produkcji wysokotechnologicznej i innowacyjnej. W warunkach światowego kryzysu finansowego, w którym najbardziej ucierpiały kraje o gospodarce wysoko rozwiniętej, m.in. kraje członkowskie UE, wskaźniki handlu zagranicznego z tą formacją polityczną znacznie się pogorszyły. W 1. 20092010 (tabela 3) obrót handlu zagranicznego spadł o 16,5\%, eksport - o 21,2\%, co spowodowało spadek udziału krajów członkowskich UE w obrocie handlu zagranicznego regionu z 39,5\% do 34\%, w eksporcie z 22,4\% do 16,9\%. W wyniku tych negatywnych czynników w 1. 2008-2010 ukształtowało się ujemne saldo w handlu z tymi krajami w wysokości 1,4 mld USD, natomiast współczynnik równowagi handlu, niezbyt wysoki w okresie przedkryzysowym $(0,46)$, spadł jeszcze bardziej, do zaledwie 0,37. Wśród krajów członkowskich Unii Europejskiej podstawowymi partnerami w handlu zagranicznym są Niemcy, Polska, Litwa, Włochy, Holandia (tabela 4). 
Tchon Li

Tabela 4. Udział wybranych krajów członkowskich UE w eksporcie i imporcie towarów obwodu grodzieńskiego

\begin{tabular}{|c|c|c|c|c|}
\hline \multirow{2}{*}{ Kraje } & \multirow{2}{*}{ Lata } & \multicolumn{3}{|c|}{ Udział kraju w handlu zagranicznym } \\
\hline & & Razem & Eksport & Import \\
\hline \multirow{3}{*}{ Niemcy } & 2008 & 11,6 & 5,1 & 18,0 \\
\hline & 2009 & 13,1 & 3,3 & 23,7 \\
\hline & 2010 & 9,5 & 2,4 & 18,1 \\
\hline \multirow{3}{*}{ Polska } & 2008 & 10,2 & 6,4 & 13,8 \\
\hline & 2009 & 10,3 & 8,6 & 12,2 \\
\hline & 2010 & 9,4 & 6,6 & 12,8 \\
\hline \multirow{3}{*}{ Litwa } & 2008 & 3,1 & 3,6 & 2,3 \\
\hline & 2009 & 3,3 & 4,4 & 2,1 \\
\hline & 2010 & 3,3 & 4,4 & 2,6 \\
\hline \multirow{3}{*}{ Włochy } & 2008 & 2,6 & 0,3 & 5,0 \\
\hline & 2009 & 2,3 & 0,4 & 4,3 \\
\hline & 2010 & 2,8 & 0,5 & 5,5 \\
\hline \multirow{3}{*}{ Holandia } & 2008 & 1,6 & 0,9 & 2,3 \\
\hline & 2009 & 1,4 & 0,9 & 2,0 \\
\hline & 2010 & 1,6 & 0,8 & 2,6 \\
\hline \multirow{3}{*}{$\begin{array}{c}\text { RAZEM } \\
\text { z wybranego }\end{array}$} & 2008 & 29,1 & 16,3 & 41,4 \\
\hline & 2009 & 30,4 & 18,0 & 44,3 \\
\hline & 2010 & 26,6 & 14,7 & 41,3 \\
\hline
\end{tabular}

Źródto: Opracowanie własne.

Wymienione 5 krajów UE dominują w handlu z regionem grodzieńskim, ich kwota zewnętrzna wynosi $78 \%$, w tym eksportu $-86,6 \%$, importu $-75,7 \%$. Udział tych krajów w 1. 2008-2010 wynosił 27-30\% całości obrotu towarów w handlu zagranicznym, $15-18 \%$ eksportu, $41-44 \%$ importu.

Ważną rolę w handlu zagranicznym odgrywają kraje spoza WNP nienależące do Unii Europejskiej (tabela 5). Handlowi z nimi właściwe jest dodatnie saldo handlu zagranicznego (253,8 mln USD), dodatnia dynamika eksportu, wyższy poziom zrównoważenia handlu (współczynnik równowagi w 2010 r. - 1,42), co pozwala częściowo zrekompensować straty poniesione w latach kryzysowych rozwoju gospodarki. W 1. 2008-2010 udział tej grupy krajów w handlu zagranicznym regionu 
Region grodzieński...

wzrósł z 15,6\% do 18,9\%, w eksporcie - z 18,1\% do 20,1\%. Tabela 5 zawiera dane o podstawowych partnerach w handlu zagranicznym - krajach spoza WNP nienależących do UE.

Tabela 5. Udział wybranych krajów nienależących do WNP i UE w eksporcie i imporcie towarów obwodu grodzieńskiego w l. 2008-2010

\begin{tabular}{|c|c|c|c|c|}
\hline \multirow{2}{*}{ Kraje } & \multirow{2}{*}{ Lata } & \multicolumn{3}{|c|}{ Udział kraju w handlu zagranicznym } \\
\hline & & Razem & Eksport & Import \\
\hline \multirow{3}{*}{ Chiny } & 2008 & 5,9 & 6,6 & 4,8 \\
\hline & 2009 & 4,8 & 6,7 & 2,8 \\
\hline & 2010 & 7,1 & 11,7 & 4,9 \\
\hline \multirow{3}{*}{ Brazylia } & 2008 & 2,5 & 4,1 & 0,6 \\
\hline & 2009 & 4,2 & 4,2 & 2,4 \\
\hline & 2010 & 2,6 & 2,2 & 1,8 \\
\hline \multirow{3}{*}{ Indie } & 2008 & 1,4 & 1,9 & 0,7 \\
\hline & 2009 & 0,9 & 0,8 & 0,9 \\
\hline & 2010 & 0,8 & 0,5 & 1,1 \\
\hline \multirow{3}{*}{ Argentyna } & 2008 & 1,1 & 1,4 & 0,8 \\
\hline & 2009 & 0,4 & 0,9 & 0,8 \\
\hline & 2010 & 1,6 & 1,6 & 2,3 \\
\hline \multirow{3}{*}{ USA } & 2008 & 1,1 & 0,6 & 1,5 \\
\hline & 2009 & 0,8 & 0,4 & 1,3 \\
\hline & 2010 & 0,6 & 0,4 & 0,9 \\
\hline \multirow{3}{*}{$\begin{array}{c}\text { RAZEM } \\
\text { z wybranego }\end{array}$} & 2008 & 12,0 & 14,6 & 8,4 \\
\hline & 2009 & 11,1 & 13,0 & 8,2 \\
\hline & 2010 & 12,7 & 16,4 & 11,0 \\
\hline
\end{tabular}

Źródto: Opracowanie własne.

Analiza struktury handlu zagranicznego z uwzględnieniem różnych krajów potwierdza istnienie pewnych problemów i pozwala wyciągnąć następujące wnioski.

Po pierwsze, handel zagraniczny obwodu grodzieńskiego jest zdywersyfikowany niewystarczająco. Na kraje WNP przypada $47 \%$ obrotu, w okresie kryzysowym wzrósł udział tej formacji polityczno-gospodarczej. Nadal dominuje Rosja 
z 37,2\% regionalnego rynku. Jeszcze bardziej ten skos jest widoczny w eksporcie, tu udział WNP sięga 63\%, Rosji - 50,8\%.

Po drugie, ujawniająca się w okresie przedkryzysowym dodatnia tendencja zwiększenia udziału krajów Unii Europejskiej w handlu z regionem grodzieńskim zaczęła spadać, a nawet miało miejsce pewne cofnięcie. Udział tych krajów zmniejszył się z 39,5\% (2008 r.) do 34\% (2010 r.), w eksporcie odpowiednio z 22,4\% do $16 \%$.

Po trzecie, handel z krajami WNP koncentruje się wokół Rosji, Ukrainy, w pewnym stopniu Kazachstanu, natomiast wśród krajów UE jest większa liczba podstawowych partnerów w handlu zagranicznym (tabela 4). Udział tych krajów przekracza ćwierć obrotu $\mathrm{w}$ handlu zagranicznym, przypada na nie $42 \%$ importu regionalnego.

Po czwarte, dodatnim czynnikiem jest zwiększenie liczby krajów spoza WNP nienależących do UE, są to przede wszystkim państwa Azji i Ameryki (tabela 5). Handel z tymi państwami jest zrównoważony, kwota eksportu jest wyższa od importu o 5,4\% (2010 r.). Jednak w tej grupie istnieją pewne problemy, na pięć krajów przypada $81,9 \%$ obrotu i $88,6 \%$ eksportu.

Po piąte, mimo że region prowadzi handel ze 119 krajami (eksportuje do 76 krajów), obrót towarów z wieloma z nich jest nieznaczny. Na liście 10 podstawowych partnerów brakuje takich krajów jak: Japonia, Wielka Brytania, Dania, Hiszpania, Korea, Singapur, Norwegia, Austria. Warto zaznaczyć, że w 2010 r. zmniejszył się handel zagraniczny z kilkoma krajami rozwiniętymi: z Australią - o 66\%, Belgią - o 56\%, Koreą - o 47\%, Singapurem - o 85\%, Francją - o 47\%, Szwecją - o 76\%, Szwajcarią - o 39\%, Japonią - o 72\%. W 2011 r. opanowano nowe rynki w 18 krajach zagranicznych, w tym: Bośnia i Hercegowina, Burkina Faso, Ghana, Gwinea, Zambia, Jordania, Kuba, Kot-d'Iwuar, Libia, Mali, Malta, Maroko, Mozambik, Nowa Zelandia, Pakistan, Senegal, Tanzania, Urugwaj. Zmiana ukierunkowania geograficznego świadczy o popycie na produkcję obwodu w nowych krajach.

\section{Stan struktury towarowej handlu zagranicznego regionu}

Badania nad stanem struktury towarowej transakcji eksportowo-importowych umożliwiają ocenę specjalizacji gospodarki regionu w eksporcie i imporcie, jej konkurencyjność na zewnętrznym rynku. Tabela 6 prezentuje dane dotyczące struktury towarowej eksportu i importu w 1. 2008-2010. 
Region grodzieński...

Tabela 6. Struktura towarowa handlu zagranicznego

obwodu grodzieńskiego w I. 2008-2010 (\% ogółu)

\begin{tabular}{|l|c|c|c|c|c|c|}
\hline \multirow{2}{*}{ Gałęzie } & \multicolumn{3}{c|}{ Eksport } & \multicolumn{3}{c|}{ Import } \\
\cline { 2 - 7 } & 2008 & 2009 & 2010 & 2008 & 2009 & 2010 \\
\hline Maszyny, urządzenia i środki transportu & 17,0 & 14,0 & 13,3 & 38,6 & 44,5 & 32,9 \\
\hline Produkty mineralne & 1,4 & 2,3 & 1,1 & 2,8 & 2,0 & 2,4 \\
\hline $\begin{array}{l}\text { Metalurgia żelaza i stali, metale kolorowe, } \\
\text { w tym wyroby z nich }\end{array}$ & 2,1 & 1,8 & 1,9 & 11,2 & 8,8 & 11,5 \\
\hline $\begin{array}{l}\text { Produkcja przemysłu chemicznego, w tym } \\
\text { włókna i nici }\end{array}$ & 30,8 & 30,6 & 31,2 & 20,7 & 19,0 & 21,8 \\
\hline $\begin{array}{l}\text { Drewno, produkcja celulozowo-papiernicza, } \\
\text { meble }\end{array}$ & 11,1 & 8,0 & 7,1 & 5,7 & 5,2 & 5,8 \\
\hline $\begin{array}{l}\text { Produkcja przemysłu lekkiego oraz surowce } \\
\text { do jej produkcji }\end{array}$ & 11,1 & 10,4 & 10,9 & 4,2 & 4,8 & 4,9 \\
\hline $\begin{array}{l}\text { Produkcja przemysłu spożywczego oraz } \\
\text { surowce do jej produkcji }\end{array}$ & 22,4 & 30,0 & 31,7 & 14,2 & 13,9 & 18,6 \\
\hline Inne & 4,1 & 2,9 & 2,8 & 2,6 & 1,8 & 2,1 \\
\hline RAZEM & 100 & 100 & 100 & 100 & 100 & 100 \\
\hline
\end{tabular}

Źródto: Opracowanie własne.

Struktura towarowa eksportu odzwierciedla istniejącą strukturę przemysłu regionalnego, w której odpowiednio przeważają przemysł spożywczy, budowa maszyn, przemysł chemiczny, przemysł lekki oraz obróbka drewna.

Wyjątkowo interesująca wydaje się analiza eksportu i importu towarów ze względu na kategorie wykorzystywania docelowego. Strukturę obrotu handlu zagranicznego z tego punktu widzenia przedstawiono w tabeli 7.

Tabela 7. Struktura handlu zagranicznego towarami obwodu grodzieńskiego ze względu na kategorie wykorzystywania docelowego (\% ogółu)

\begin{tabular}{|l|c|c|c|c|c|c|c|c|c||}
\hline \multirow{2}{*}{ Kategoria towarów } & \multicolumn{3}{|c|}{ Eksport } & \multicolumn{3}{c|}{ Import } & \multicolumn{3}{c|}{$\begin{array}{c}\text { Obrót w handlu } \\
\text { zagranicznym }\end{array}$} \\
\cline { 2 - 12 } & 2008 & 2009 & 2010 & 2008 & 2009 & 2010 & 2008 & 2009 & 2010 \\
\hline Inwestycyjne & 4,5 & 4,2 & 4,0 & 16,7 & 20,8 & 20,1 & 11,2 & 12,2 & 11,2 \\
\hline Przemysłowe & 59,3 & 54,0 & 52,5 & 63,2 & 56,4 & 67,7 & 60,6 & 55,1 & 59,2 \\
\hline Konsumpcyjne & 35,5 & 41,5 & 43,0 & 19,3 & 21,9 & 11,6 & 27,6 & 32,1 & 28,7 \\
\hline
\end{tabular}

Źródło: Obliczono wg danych Głównego Urzędu Statystycznego Obwodu Grodzieńskiego. 
Analizując dane tabeli 7, warto zwrócić uwagę przede wszystkim na znikomy udział grupy inwestycji w eksporcie towarów. Jak wiadomo, właśnie ta grupa odzwierciedla potencjał przemysłowy kraju, regionu, podmiotów gospodarki, jego poziom techniczny i innowacyjny, konkurencyjność; jej udział wahał się w granicach $4,5-4,0 \% \%$, pozostając na poziomie lat 2004-2007, czyli prawie 2,5 raza niżej niż w RB (2009 r. - 9,4\%). Z kolei wskaźnik w kraju jest dość niski, biorąc pod uwagę konieczność zwiększenia efektywności gospodarki narodowej.

Jak wynika z doświadczeń światowych, wzrost inwestycyjnej składowej w imporcie sprzyja zwiększeniu efektywności gospodarowania, obniżeniu materiałochłonności i energochłonności dochodu ogólnego dzięki odnowieniu funduszy podstawowych, wdrażaniu nowych - przede wszystkim innowacyjnych - technologii oraz osiągnięciu w końcu lepszej konkurencyjności produkcji na rynku zewnętrznym. Jak wynika z tabeli 7, w 1. 2008-2010 udział importu inwestycyjnego w imporcie wynosił 16,7-20,1\%, czyli prawie dwukrotnie więcej niż w ogóle w kraju (2009 r. - 10,1\%). Co prawda, ważną rolę w tych statystykach odgrywa specyfika przygranicznego usytuowania regionu grodzieńskiego. Warto zwrócić uwagę, że, chociaż udział towarów inwestycyjnych w imporcie jest wyższy niż w kraju, jest to jednak o wiele mniej niż w Polsce, gdzie udział tej grupy towarów w imporcie w 2008 r. wyniósł $40 \%$.

Dość niepokojącym sygnałem wskazującym na pogarszającą się sytuację w strukturze importu jest wzrost roli towarów pośrednich, który świadczy o zwiększeniu surowcowego ukierunkowania produkcji regionu, jego wysokiej materiałochłonności i energochłonności, nasilającego się uzależnienia gospodarki. Jak widać z tabeli 7, w 2010 r. udział towarów pośrednich w imporcie wzrósł z 56,4\% do $67,7 \%$. Zestawienie kwoty towarów pośrednich w regionie i w kraju jest na korzyść regionu. W 1. 2008-2009 udział towarów pośrednich w handlu zagranicznym Białorusi wynosił odpowiednio $73,1 \%$ i $71 \%$ [4, s. 69], natomiast w regionalnym obrocie w handlu zagranicznym w 1. 2008-2010, jak widać z tabeli $7-60,6 \%, 55,1 \%$, $59,2 \%$. Taka ocena jednak miałaby raczej charakter formalny. Wiadomo, że podstawową przyczyną ujemnego salda handlu zagranicznego jest zależność gospodarki narodowej od importu zasobów energetycznych, lecz przedsiębiorstwa i regiony nie importują ich bezpośrednio. Kupuje je państwo, właśnie tym można wytłumaczyć na pierwszy rzut oka ,niewytłumaczalną” statystykę świadczącą o tym, iż wszystkie regiony RB mają dodatnie saldo handlu zagranicznego, Mińsk natomiast - ujemne. W 2009 r. udział towarów energetycznych w imporcie kraju wyniósł 39,3\%, w imporcie regionu grodzieńskiego - 0,2\%, a w 2010 r. - 0,1\% (wg danych Głównego Urzędu Statystycznego Obwodu Grodzieńskiego). Tak więc nie licząc towarów energetycznych, krajowa kwota importu towarów pośrednich wyniosła w 2009 r. $31,7 \%$ (71\%-39,3\%), regionalna natomiast - 67,5\% (67,7\%-0,2\%). 
Region grodzieński...

Ocena specjalizacji koszyka eksportowego. W obrębie eksportu regionu grodzieńskiego brakuje produktów przemysłu petrochemicznego, w związku z czym koncentracja eksportu w kilku pozycjach towarowych nie jest tak oczywista, chociaż jest wysoka. Do analizy osobliwości specjalizacji koszyka eksportowego wyodrębniono 5 podstawowych grup towarów według Nomenklatury Towarowej Zagranicznej Działalności Ekonomicznej Republiki Białoruś (NT ZDzE RB) ze względu na dwie pierwsze liczby. Dane te zawiera tabela 8.

Tabela 8. Podstawowe grupy towarów eksportu w obwodzie grodzieńskim (w \%)

\begin{tabular}{|c|c|c|c|c|c|c|c|c|c|}
\hline \multirow[b]{3}{*}{ 온 } & $\begin{array}{l}\text { dNM ezods } \\
\text { !шue!esy Z }\end{array}$ & ' & $\begin{array}{l}\text { ơ } \\
\text { Ni }\end{array}$ & $\stackrel{\mathfrak{N}}{\mathfrak{N}}$ & ' & $\frac{\infty}{N}$ & 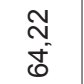 & $\begin{array}{l}\stackrel{\infty}{ᄉ} \\
\infty^{-}\end{array}$ & 으 \\
\hline & 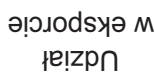 & \begin{tabular}{l}
$\stackrel{\mathscr{N}}{N}$ \\
\multirow{\sim}{\sim}{}
\end{tabular} & 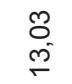 & $\begin{array}{l}\text { mे } \\
\infty\end{array}$ & $\frac{0}{\infty}$ & $\begin{array}{l}\qquad 0 \\
6 \\
6\end{array}$ & $\begin{array}{l}\infty \\
m \\
\stackrel{\square}{q}\end{array}$ & 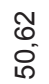 & 음 \\
\hline & $\begin{array}{l}\sum_{N}^{N} \\
\text { N }\end{array}$ & $\begin{array}{l}\frac{\bar{\pi}}{\frac{\pi}{0}} \\
\frac{\pi}{z}\end{array}$ & 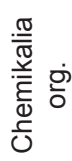 & $\begin{array}{l}\widehat{N} \\
\text { 离 } \\
\text { IN }\end{array}$ & 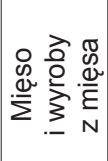 & 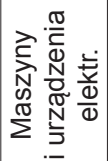 & & & \\
\hline & 之 亮 & ¿ & 尺 & $\bar{m}$ & $\widetilde{\delta}$ & $\stackrel{\wp}{\infty}$ & & & \\
\hline \multirow{4}{*}{ 오 } & $\begin{array}{l}\text { dNM ezods } \\
\text { !шue!edy Z }\end{array}$ & ' & $\begin{array}{l}\text { Oे } \\
\text { î }\end{array}$ & $\begin{array}{l}\text { qu } \\
\bar{N}\end{array}$ & ' & 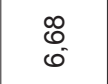 & 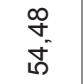 & $\begin{array}{l}\text { గิ } \\
\text { రุ }\end{array}$ & 음 \\
\hline & $\begin{array}{c}\text { ə!઼ıodsyә M } \\
\text { łe!zp }\end{array}$ & 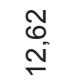 & 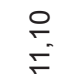 & $\begin{array}{l}\text { đิ } \\
\text { के }\end{array}$ & $\begin{array}{l}\text { ले } \\
\infty\end{array}$ & $\begin{array}{l}\infty \\
\infty \\
\infty\end{array}$ & $\begin{array}{l}\stackrel{L}{\circ} \\
\stackrel{+}{+}\end{array}$ & 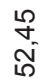 & 음 \\
\hline & $\begin{array}{l}\sum_{N}^{\mathbb{N}} \\
\text { N } \\
Z\end{array}$ & $\begin{array}{l}\frac{\bar{\pi}}{0} \\
\frac{\pi}{2}\end{array}$ & 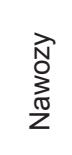 & 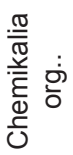 & 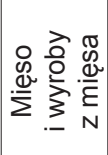 & 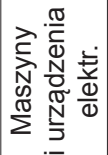 & & & \\
\hline & 之 & ¿ & $\bar{m}$ & $\stackrel{\text { N }}{ }$ & ऽ & $\stackrel{\infty}{\infty}$ & & & \\
\hline \multirow{4}{*}{$\stackrel{\infty}{\circ}$} & $\begin{array}{l}\text { dNM ezods } \\
\text { !шue!esy Z }\end{array}$ & $\begin{array}{l}\text { O } \\
\text { Ñ }\end{array}$ & $\begin{array}{l}\sigma_{0} \\
\infty^{\circ}\end{array}$ & ర్ & ' & $\begin{array}{l}L_{0}^{\circ} \\
\infty\end{array}$ & $\begin{array}{c}0 \\
\tilde{0}\end{array}$ & $\begin{array}{l}\forall \\
\dot{ల}\end{array}$ & 음 \\
\hline & 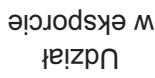 & 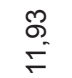 & $\stackrel{\text { mे }}{\stackrel{-}{\leftarrow}}$ & $\stackrel{\stackrel{m}{m}}{\rightleftarrows}$ & $\begin{array}{l}\bar{t} \\
\sigma\end{array}$ & $\begin{array}{l}\text { N } \\
0\end{array}$ & $\stackrel{\bar{m}}{\stackrel{5}{\sigma}}$ & $\begin{array}{l}8 \\
\text { กิ } \\
\text { గิ }\end{array}$ & 음 \\
\hline & $\begin{array}{l}\underset{N}{\mathbb{N}} \\
\underset{Z}{Z}\end{array}$ & 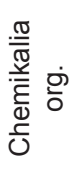 & 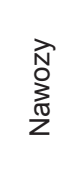 & $\begin{array}{l}\frac{\bar{\pi}}{\frac{\pi}{0}} \\
\frac{\pi}{2}\end{array}$ & 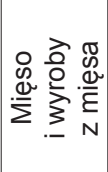 & 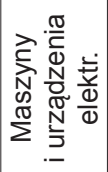 & 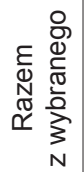 & 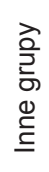 & $\begin{array}{l}\varepsilon \\
\mathbb{D} \\
\mathbb{N} \\
\widetilde{x}\end{array}$ \\
\hline & $z$ 旁 & 尺 & $\bar{m}$ & ¿ & $\widetilde{\curvearrowright}$ & $œ$ & & & \\
\hline
\end{tabular}

Źródło: Obliczono wg danych Głównego Urzędu Statystycznego Obwodu Grodzieńskiego. 
Analiza danych zawartych w tabeli 8 pozwala stwierdzić zwiększenie koncentracji towarów eksportu regionalnego w 1. 2008-2010 do 49,38\%, innymi słowy połowa koszyka eksportowego stanowią pięć grup towarowych, a eksportuje się towary 86 z 97 grup towarowych reprezentowanych w NT ZDzE RB. Porównajmy to do danych z niektórych małych krajów z gospodarką „otwartą”, gdzie udział 5 podstawowych grup towarowych wyniósł (w 2005 r.) w Danii - 22,87\%, Holandii 23,96\%, Portugalii - 24,37\%, Belgii - 29,86\% [6, s. 24, 25, 29, 32].

Jeszcze w większym stopniu koncentruje się eksport do krajów spoza WNP, w 2010 r. udział grup towarowych wg kodów NT ZDzE RB 02; 04; 29; 31; 85 wyniósł ponad 64\% eksportu na rynku poza WNP (tab. 8). Znamienne, że na jednego eksportera - Otwartą Spółkę Akcyjną „Grodno AZOT” - przypada 55,5\% całego eksportu regionalnego do krajów WNP. W takiej sytuacji gwałtowny spadek produkcji z jakiegokolwiek powodu może doprowadzić do upadku sprzedaży eksportowej.

Wnioski o dotkniętym hipertrofią rozwoju poszczególnych branży potwierdza analiza koszyka eksportowego według pozycji towarowych NT ZDzE RB ze względu na cztery liczby (patrz tabelę 9).

Tabela 9. Podstawowe pozycje towarowe koszyka eksportowego regionu grodzieńskiego (w \%)

\begin{tabular}{|c|c|c|c|c|c|}
\hline \multirow[b]{2}{*}{$\mathrm{Nr}$} & \multicolumn{2}{|l|}{2009} & \multirow[b]{2}{*}{$\mathrm{Nr}$} & \multicolumn{2}{|l|}{2010} \\
\hline & Nazwa pozycji towarowej & $\begin{array}{l}\text { Udział } \\
\text { w eksporcie } \\
\text { regionalnym }\end{array}$ & & Nazwa pozycji towarowej & $\begin{array}{l}\text { Udział } \\
\text { w eksporcie } \\
\text { regionalnym }\end{array}$ \\
\hline 3102 & Nawozy azotowe & 11,11 & 2933 & $\begin{array}{c}\text { Związki heterocykliczne } \\
\text { zawierające tylko } \\
\text { heteroatom(y) azotu }\end{array}$ & 10,78 \\
\hline 2933 & $\begin{array}{c}\text { Związki heterocykliczne } \\
\text { zawierające tylko } \\
\text { heteroatom(y) azotu }\end{array}$ & 8,04 & 3102 & Nawozy azotowe & 8,34 \\
\hline 0406 & Sery białe i żółte & 5,76 & 0406 & Sery białe i żółte & 6,08 \\
\hline 6115 & $\begin{array}{l}\text { Rajstopy, pończochy, } \\
\text { podkolanówki, skarpety }\end{array}$ & 4,05 & 1701 & Cukier & 4,61 \\
\hline 0402 & $\begin{array}{l}\text { Mleko i śmietanka, } \\
\text { skondensowane lub } \\
\text { z cukrem }\end{array}$ & 3,86 & 6115 & $\begin{array}{l}\text { Rajstopy, pończochy, } \\
\text { podkolanówki, skarpety }\end{array}$ & 4,59 \\
\hline 9403 & Meble inne & 3,83 & 0402 & $\begin{array}{c}\text { Mleko i śmietanka, } \\
\text { skondensowane lub } \\
\text { z cukrem }\end{array}$ & 3,73 \\
\hline 0202 & Mięso bydła rogatego & 3,34 & 9403 & Meble inne & 3,61 \\
\hline 5402 & $\begin{array}{l}\text { Nicie kompleksowe, } \\
\text { sztuczne }\end{array}$ & 3,30 & 5402 & Nici kompleksowe, sztuczne & 3,51 \\
\hline 1701 & Cukier & 3,30 & 5902 & Materiały kordowe do opon & 2,78 \\
\hline 5902 & Materiały kordowe do opon & 2,66 & 0405 & Masło śmietankowe & 2,18 \\
\hline & Razem z wybranego & 49,25 & & & 50,21 \\
\hline
\end{tabular}

Źródto: Obliczono wg danych Głównego Urzędu Statystycznego Obwodu Grodzieńskiego. 
Obwód eksportuje setki rodzajów towarów, lecz jak wynika z danych tabeli 9 , połowa regionalnego eksportu przypada na dziesięć pozycji towarowych, w dużej części powtarzających się. Wskazaną „dziesiątkę” w zasadzie stanowi produkcja o średniej (towary przemysłu chemicznego i budowy maszyn) oraz niskiej naukochłonności, o niskiej wartości dodanej. Zatem produkcję przemysłu spożywczego i przemysłu chemicznego, których ,udział” w koszyku eksportowym wynosi $60 \%$ (patrz tab. 6), cechują niższa w przemyśle regionu wartość dodana w kosztach produkcji oraz większe wydatki zasobów materialnych na jej produkcję.

\section{Zakończenie}

W wyniku badań dochodzimy do następujących wniosków i określamy podstawowe, priorytetowe kierunki działań w zakresie zwiększenia efektywności i zrównoważenia sektora handlu zagranicznego w gospodarce regionu grodzieńskiego:

1. Procesy kryzysowe 1. 2009-2010 w światowym systemie finansów i gospodarki wywarły wpływ na dynamikę obrotu w handlu zagranicznym. W 2009 r. odnotowano spadek o 22\%; mimo że w 2010 r. sytuacja znacznie się polepszyła, nie osiągnięto poziomu przedkryzysowego (2008 r.). Udział regionu w handlu zagranicznym kraju nie odpowiada istniejącemu potencjałowi. Tempo wzrostu eksportu jest niższe od tempa wzrostu produkcji przemysłowej, współczynnik korelacji charakteryzujący stosunki wzajemne między tymi wskaźnikami jest niższy od 1 i ujawnia tendencję do dalszego obniżania się.

2. Wskaźnik eksportu na głowę mieszkańca nadal jest niski i znacznie odbiega od niektórych byłych republik ZSRR i państw członkowskich RWPG, którym właściwe były identyczna struktura gospodarki narodowej, jej organizacja i zarządzanie: w porównaniu do Czech jest mniejszy 9,4 raza, Słowacji $-8,7$, Węgier - 6,8, Estonii - 5,9, Litwy - 5, Łotwy i Polski - 2,9, Bułgarii -2 razy.

3. Nacisk kładzie się na handel z krajami WNP (47\% obrotu, 63\% eksportu). Dominującym partnerem jest Rosja. W 2010 r. udział Rosji w handlu zagranicznym wyniósł $81,9 \%$, w eksporcie $-84,7 \%$. Podobna sytuacja, naszym zdaniem, wzbudza pewne obawy, ponieważ pogorszenie sytuacji ekonomicznej w tym kraju może spowodować upadek eksportu regionalnego. Na rynku rosyjskim jest realizowane prawie 100\% eksportowanej przez region wołowiny, wieprzowiny, drobiu, jaj, mleka, śmietanki, twarogu i serów, masła; ponad 90\% obuwia, farb i lakierów, wyrobów z żelaza i stali.

4. Niewystarczające zdywersyfikowanie handlu zagranicznego pod względem geograficznym negatywnie wpływało na stosunki regionu z krajami UE-27, ich udział obniżył się do 34\%, współczynnik równowagi (niewysoki w okre- 
sie przedkryzysowym) spadł do 0,37. Udział Niemiec, Polski, Litwy, Włoch i Holandii wynosi $78 \% \mathrm{w}$ obrocie w handlu zagranicznym z krajami UE-27 i 27-30\% w ogóle w regionie.

5. Pewną rekompensatą strat $\mathrm{w}$ okresie przedkryzysowym stało się zwiększenie udziału krajów nienależących ani do WNP, ani do UE-27, z 15,6\% do $18,9 \%$, w eksporcie - z 18,1\% do 20,1\%. Jednak w tej grupie poziom dywersyfikacji nie odpowiada realnym możliwościom. Na takie kraje jak Chiny, Brazylia, Indie, Argentyna i USA przypada 81,9\% obrotu w handlu i 88,6\% eksportu do tych krajów.

6. Branżowa struktura handlu zagranicznego odzwierciedla ukształtowaną strukturę przemysłu regionalnego. Równocześnie zaznaczmy, że stopień obecności podstawowych gałęzi przemysłu na rynku zewnętrznym jest wyższy od ich udziału w gospodarce regionu.

7. Chronicznie niski pozostaje poziom grupy inwestycyjnej w eksporcie towarów, ponadto w okresie kryzysu spadł on z 4,5\% do 4\%. Bardziej racjonalnie $\mathrm{z}$ tego punktu widzenia wygląda struktura importu, zwłaszcza $\mathrm{z}$ krajów spoza WNP. W 1. 2008-2010 ustaliła się dodatnia tendencja do zwiększenia importu towarów konsumpcyjnych i inwestycyjnych z $16,7 \%$ do $20,1 \%$ oraz z $63,2 \%$ do $67,7 \%$, przy czym import towarów konsumpcyjnych zmniejszył się dwukrotnie.

8. Eksport regionalny cechuje wysoki stopień specjalizacji i koncentracji koszyka eksportowego oraz zmniejszenie zdywersyfikowania przez redukcję zakresu i nomenklatury towarów eksportowanych i zwiększenia poszczególnych rodzajów towarów w ogóle ich dostaw na rynki zewnętrzne. W regionie grodzieńskim są to organiczne związki chemiczne, nawozy, produkcja mleczna i produkcja mięsna. Taka sytuacja świadczy o zwiększonym narażeniu eksportu i zależności od zmian zachodzących na rynku światowym.

9. W koszyku eksportowym powinna być naukochłonna produkcja z różnych branż gospodarki, o wysokiej wartości dodanej. Rozwiązanie tego zadania jest niemożliwe w tymczasowym programie, jest ono uzależnione od stosowania kardynalnych środków skierowanych na zwiększenie naukochłonności regionalnego sektora gospodarki, tworzeniem infrastruktury innowacji, wspieraniem działalności innowacyjnej, transferem technologii, przyciąganiem inwestycji zagranicznych do naukochłonnych i wysokotechnologicznych sektorów gospodarki. 


\section{GRODNO REGION IN INTERNATIONAL ECONOMIC RELATIONS}

In general, analysis of international economic relations concern interstate relations or discuss relationships of other subjects (usually corporations) in terms of state. The paper discusses international economic relations of the Grodno Region, presenting subjective (economic partners), objective (goods and services) and structural aspects (statistics). Effects of the 2009 and 2010 global financial and economic crisis on the growth of the Grodno Region's external trade circuit is commented on. A change in the direction of international economic expansion to and from the Grodno Region (the dominance of Russia, the EU weakening and the activation of other directions) is noticed. Attention is paid to the growth of consumption and to a natural reaction of the market, i.e. the increase in the supply of consumer goods' export. The beginnings of regional export specialization is noted. In the conclusion the necessity for innovation and a knowledge based economy is underlined.

Keywords:

Belarus, Grodno Region, transboundary cooperation, internationalization of regions 